\title{
Economic and environmental approach to agricultural and rural development
}

\author{
Yulia Pavlova* \\ Cheboksary Cooperative Institute (branch) of the Russian University of Cooperation, 428025, \\ 24, M. Gorky Prospekt, Cheboksary, Chuvash Republic, Russian Federation
}

\begin{abstract}
This article discusses the choice of a model for development of agriculture and, accordingly, rural areas, taking into account the economic and environmental approach. The main producers of agricultural products and users of land resources are not only large and small agricultural organizations, but also personal subsidiary plots. The efficiency of use of land resources by households is much higher than in other agricultural organizations. Personal subsidiary plots in production of agricultural products use resource-saving technologies. Today, personal subsidiary plots remain without due attention from the state, business and the scientific community. They are also deprived of economic, financial, informational, technological, and human resources. As a practical implementation of theoretical conclusions, the article offers the implementation of the Bioekopolis project. In the territory of the Kanashsky district of the Chuvash Republic on the basis of Atalanu LLC from 2016 to 2021. experimental work was carried out to create individual elements of a small-scale rural settlement based on the principles of bioecopolis. The results of scientific and experimental design work, the experience of operating a residential building and outbuildings, the established operating mode of innovation gave the basis for development of an innovative project and the opportunity for its subsequent replication.
\end{abstract}

\section{Introduction}

The relevance and scientific significance of the article is determined by the solution of issues of ecology, economic growth, improving the well-being of the rural population, food provision with ecologically clean products of citizens by agricultural producers. Wherein, it is observed that the ecological-socio-economic role of rural households in the course of the agrarian reforms carried out did not decrease, but, on the contrary, even increased. Rural farmsteads during their more than a century of existence contributed not only to the survival of the rural population during the aggravation of ecological, socio-economic situations in the country, but also helped the city. Use of an economic and environmental approach to the choice of options for the development of agriculture makes it possible to study the relationship between agricultural producers and their environment. The object of the study is agricultural producers. The subject of the study is organization and functioning

\footnotetext{
*Corresponding author: inet2@mail.ru
} 
of agriculture and rural areas in conditions of environmental preservation. The aim of the study is to search for such options for development of the economy of agriculture and rural areas, which imply the rational use of limited natural resources, the renewal of used natural resources, the use of closed-cycle technologies for the production of agricultural products, the use of agricultural waste and waste products of the rural population as resources for subsequent agricultural production.

\section{Methods}

In this paper, we used a systematic approach in studying the cause-and-effect relationships of the current state of agricultural development, an economic-statistical method in analyzing the efficiency of resource use by agricultural producers, an abstractlogical method when searching for models of economic and environmental development of agricultural territories.

The market transformations taking place in the agriculture of the Russian Federation over the past 30 years have led to a multitude of economic activities in this sector of the economy. This can be seen from the analysis of agricultural production by various agricultural producers according to Figures 1 and 2.

\section{Agricultural producers}
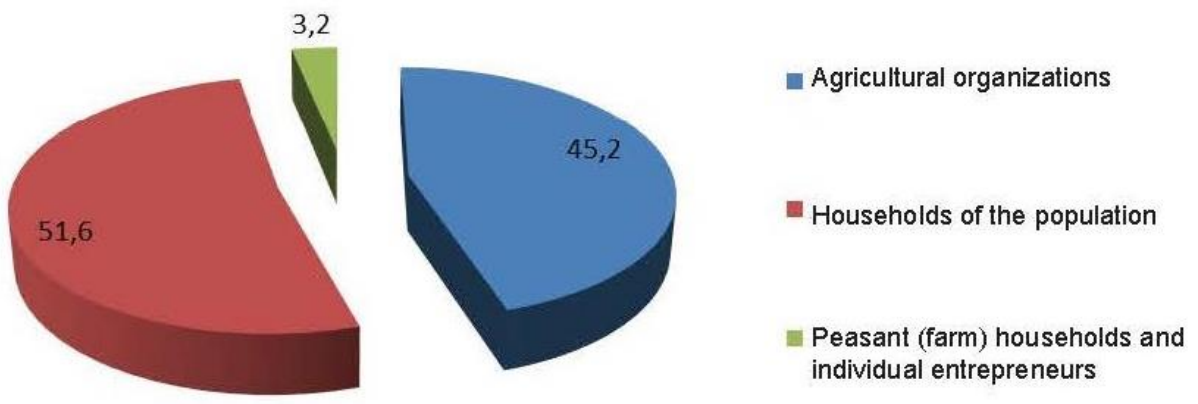

Fig. 1. The structure of agricultural products in the Russian Federation by categories of agricultural producers in 2000, \% (according to: Agriculture in Russia, 2019: Statistical collection/Rosstat, M., 2019, 91 p.).

According to the data in Figure 1, it can be seen that in the composition of agricultural producers in the Russian Federation in 2000, agricultural organizations accounted for $45.2 \%$, household farms accounted for $51.6 \%$, and peasant farms and individual entrepreneurs accounted for $3.2 \%$.

Consider how this structure has changed over time, as shown in Figure 2. 


\section{Agricultural producers}

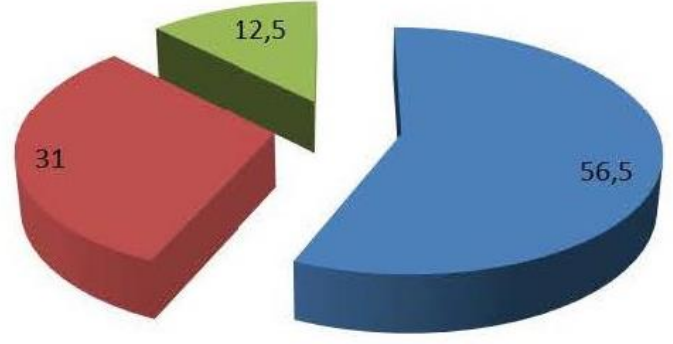

Agricultural organizations

Households of the population

Peasant (farm) households and individual entrepreneurs

Fig. 2. The structure of agricultural products in the Russian Federation by categories of agricultural producers in 2018, \% (according to: Agriculture in Russia, 2019: Statistical collection/Rosstat. M., 2019, 91 p.).

So, from Figure 2 it can be seen that in 2018, agricultural organizations account for $56.5 \%$ of agricultural producers in the Russian Federation, household farms account for $31 \%$, peasant (farm) households and individual entrepreneurs make up $12.5 \%$.

Therefore, it can be seen that over the period under review, personal subsidiary plots still continue to play an important role in providing food to the country's population, and are actively involved in economic turnover.

Land is the main, special, irreplaceable and the only means of production for agriculture. Rational use of land resources affects the performance of agricultural producers. Moreover, the land belongs to the category of national wealth. In the structure of the land fund of Russia at the beginning of 2019, agricultural land occupies 383.5 million hectares or $22.3 \%$. For the systematic production of agricultural products, only agricultural land is used. Their share is 197.7 million hectares, or $11.5 \%$ of the total land fund of Russia. In the structure of agricultural land, the total area of arable land is 116.24 million hectares or $58.8 \%$ [4]. Wherein, as can be seen from the report on the state and use of agricultural land in the Russian Federation in 2018, there is a decrease in the area of land occupied by agricultural land in 1990-2018 due to their transfer to lands of other categories due to misuse. Therefore, the issues of efficient use of land resources are becoming relevant for all categories of agricultural producers.

Let us analyze the efficiency of use of land resources according to Rosstat data in Table 1.

Table 1. Comparative efficiency of land use by categories of agricultural producers of the Russian Federation for 2001-2018 (according to the Federal State Statistics Service (Rosstat), 2019).

\begin{tabular}{|l|c|c|c|c|c|}
\hline \multirow{2}{*}{$\begin{array}{c}\text { Categories of agricultural } \\
\text { producers }\end{array}$} & \multicolumn{6}{|c|}{$\begin{array}{c}\text { The cost of gross production per 1 ha of } \\
\text { agricultural land, thousand rubles/ha }\end{array}$} \\
\cline { 2 - 7 } & $\mathbf{2 0 0 1}$ & $\mathbf{2 0 0 8}$ & $\mathbf{2 0 1 1}$ & $\mathbf{2 0 1 4}$ & $\mathbf{2 0 1 8}$ \\
\hline Total & 4.91 & 12.89 & 13.73 & 22.58 & 27.66 \\
\hline including & 2.74 & 9.45 & 9.54 & 18.27 & 26.31 \\
\hline Agricultural organizations & 2.25 & 13.16 & 7.86 & 16.48 & 19.32 \\
\hline $\begin{array}{l}\text { Peasant (farming) households } \\
\text { and individual entrepreneurs }\end{array}$ & 46.20 & 38.69 & 42.66 & 53.10 & 57.85 \\
\hline Households of the population & &
\end{tabular}


As can be seen from the above Table 1, the calculations of the comparative efficiency of land use by categories of agricultural producers of the Russian Federation for 2001-2018 indicate that in personal subsidiary plots land resources are used much more efficiently. So, for example, the cost of gross production per 1 ha of agricultural land in 2018 in agricultural organizations amounted to 26.31 thousand rubles/ha, in peasant (farm) households and individual entrepreneurs - 19.32 thousand rubles/ha, and for households 57.85 thousand rubles/ha. Therefore, the efficiency of land use in households in 2018 is two times higher than in agricultural organizations, and almost three times higher than in peasant (farm) households and farms of individual entrepreneurs.

Let us analyze the structure of use of agricultural land by all categories of agricultural producers of the Russian Federation at the beginning of 2019 according to the data in Table 2.

Table 2. The structure of use of agricultural land by all categories of agricultural producers of the Russian Federation as of January 01, 2019 (according to the Federal State Statistics Service

(Rosstat), 2019).

\begin{tabular}{|l|c|c|c|c|c|c|}
\hline \multirow{2}{*}{$\begin{array}{c}\text { Categories of } \\
\text { agricultural } \\
\text { producers }\end{array}$} & \multirow{2}{*}{$\begin{array}{c}\text { Agricul } \\
\text { tural } \\
\text { land, } \\
\text { total }\end{array}$} & $\begin{array}{c}\text { Arable } \\
\text { land }\end{array}$ & $\begin{array}{c}\text { Hayfiel } \\
\text { ds }\end{array}$ & Pasture & $\begin{array}{c}\text { Perenni } \\
\text { al } \\
\text { planting } \\
\text { s }\end{array}$ & $\begin{array}{c}\text { Depos } \\
\text { it }\end{array}$ \\
\hline Total & 100 & 60.5 & 8.9 & 27.8 & 0.9 & 1.9 \\
\hline of them & 100 & 64.7 & 8.2 & 2.9 & 0.3 & 1.9 \\
\hline $\begin{array}{l}\text { agricultural } \\
\text { organizations }\end{array}$ & 100 & 68.4 & 4.6 & 26.2 & 0.1 & 0.7 \\
\hline $\begin{array}{l}\text { peasant (farming) } \\
\text { households and } \\
\text { individual } \\
\text { entrepreneurs }\end{array}$ & 100 & 62.9 & 9.4 & 20.5 & 4.0 & 3.2 \\
\hline $\begin{array}{l}\text { households of the } \\
\text { population }\end{array}$ & 100 & & & & & \\
\hline
\end{tabular}

The existing structure of use of agricultural land by all categories of agricultural producers of the Russian Federation for 2001-2018 does not change much. It remains approximately the same as shown in Table 2 . Despite the approximately identical structure of agricultural land use, the efficiency of land use in households remains higher.

In addition to cost indicators, to assess the efficiency of use of land resources by agricultural producers, natural indicators are also used. So, if the yield of potatoes in farms of all categories in 2018 was $170 \mathrm{c} /$ ha, then in households - $151 \mathrm{c} /$ ha. The yield of vegetables in farms of all categories in 2018 was $243 \mathrm{c} / \mathrm{ha}$, then in households $-218 \mathrm{c} / \mathrm{ha}$. It shall be borne in mind that personal subsidiary plots in the production of agricultural products do not worsen the quality of the land, because use organic fertilizers and do not use heavy agricultural machinery.

Thus, our studies indicate that personal subsidiary plots use land resources for production of agricultural products with more efficient and most benign technologies.

\section{Results}

On July 29 of this 2021 the World Environmental Debt Day came. Therefore, by this day we have spent all the Earth's resources that it can restore in a year, and we are already spending the resources of future generations [15]. This does not fit with the concept of sustainable development, which implies today's economic growth and development while 
preserving the environment and resources without compromising the opportunities of future generations. For the first time the concept of "socio-economic, environmentally oriented development" was formulated 50 years ago by M. Strong at the UN Conference on Environmental Protection [3].

The closest interaction with the environment occurs in the rural person, and agriculture is the primary sector of the economy that produces food. Wherein, according to the experience of world economic development, sustainable agriculture for the planet is more effective than traditional forms of farming. It leads to production of more products, the creation of additional jobs, and etc. ultimately, making a profit for agricultural producers. So, with the same production volumes, sustainable agriculture, compared to traditional agriculture, provides more jobs per hectare of land used. Sustainable agriculture brings benefits not only to the producer, but also to the consumer and ultimately to society as a whole. Thus, in the coming years, a multiple growth of the organic food market in the European Union is predicted [5].

Also, the effective use of available resources in conditions of their limitedness becomes a new opportunity for economic growth of the economy. More and more business entities are beginning to use closed-cycle production technologies. World practice shows that use of such technologies also leads to an increase in household incomes [5]. Increased efficiency in use of resources also leads to creation of additional jobs. Therefore, agriculture, like no other sector of the economy, can use the new opportunities for growth and development, considering the economic and environmental approach.

With the growing role of natural resources in the global economy in the Russian Federation, the role of agriculture increases, since they are becoming the most important resource for economic growth and development. The economic and ecological processes taking place in the country lead to the loss of the development of agricultural land, on the one hand. On the other hand, it is agricultural production that is most strongly influenced by environmental processes, since agriculture uses land, flora and fauna as means of production.

The last two years of the life of society in the context of the COVID-19 pandemic have clearly demonstrated the benefits and attractiveness of rural lifestyles. These are remoteness, isolation, the ability to go out for walks, the provision of our own food, the ability to work remotely (though, where there is high-speed Internet), and etc. This led to the outflow of part of the urban population to the countryside. Some moved to live in the countryside during this lockdown period, or some families from city apartments moved to private houses in the countryside, selling their city apartments, acquiring land and houses on a permanent basis.

All these factors make it possible to preserve the economic, social, ecological potential of personal subsidiary plots. The task of modern science and practice is to develop such models for development of rural areas that would improve the ecological situation, preserve the environment, develop production activities, improve the demographic situation in rural areas, create additional jobs in rural areas and not only in agricultural production, expand the spatial communication environment for the inhabitants of the village.

"Stable socio-economic development of rural areas, an increase in agricultural production, an increase in the efficiency of agriculture, achievement of full employment of the rural population and an increase in their standard of living, rational use of land", which are noted in the Strategy for Sustainable Development of Rural Areas of the Russian Federation for the period up to 2030 year, adopted by the order of the Government of the Russian Federation dated February 2, 2015 No. 151-r, cannot be achieved without taking into account the economic and environmental approach when developing a conceptual model for development of rural areas. The reasons are urgent not only economic, but also environmental problems. It is impossible to deny the role of state and local government 
bodies in environmental protection in choosing a model for the development of rural areas. Within implementation of these models, it is necessary to use an economic and environmental approach.

As a way to solve urgent socio-economic problems of sustainable development of rural areas, we consider the development of rural settlements on the principles of bioeclopolis. In the comprehensive program for development of biotechnologies in the Russian Federation approved by the Government of the Russian Federation on April 24, 2012 No. 1853p-P8, the following definition is given: "Bioekopolis is a small settlement inscribed in an ecologically clean landscape, created using biotechnological methods of agricultural farming, with pre-fabricated, cheap and energy efficient homesteads".

Environmental problems have become global in nature and from the standpoint of agribusiness they occupy a dominant position in assessing any steps to increase the sustainability of production. It shall be noted that those forms of management that were inherent in the Russian way of life in rural areas, excluding large-scale production, did not accumulate major environmental problems for the territories, but, on the contrary, contributed to the balanced interaction of natural factors with human activities. In this case, we are talking about peasant farmsteads. Their stability has been proven by their long existence. The main principle of their activity is an almost automatic method of production isolation in a local space with a minimum consumption of non-renewable resources. With the transition to small-scale production, in terms of ecology, they are the most acceptable for the future, which is noted in the work "Models of the production of eco products (revival of the deep territories of Russia)" [9].

In the following papers of some authors, to intensify agro-industrial production, to accelerate development of scientific and technological progress in rural areas, it is offered to use renewable energy sources (RES) for autonomous power supply of a number of rural objects $[1,2]$. However, in the country today, the potential possibilities of using renewable energy sources in the sustainable development of rural areas have not been sufficiently studied, and there is even less experience of their use in the development of rural households. There are also no methods for selecting different types of renewable energy sources in their overall energy balance. There are separate studies that are aimed at studying the possibility of using RES in industrial agricultural production [12].

Therefore, personal subsidiary plots, even without realizing it, in their development and implementation of economic activities consider all four laws of ecology, formulated by B. Kommoner [8] in the form of aphorisms. We believe that in the future the greening of production activities in agriculture shall be promoted by all categories of agricultural producers. It is necessary to seek to reduce environmental damage by all categories of agricultural producers. The balance of economic and environmental interests of modern society is most fully observed precisely in the development of personal subsidiary plots. In their historical existence, there is a social orientation, environmental acceptability, the priority of protecting human life and health, improving the state of the environment, reproduction of natural resources, rational use of natural resources. Therefore, in order to improve the ecological situation and preserve the environment, it is necessary to create an economic interest of all agricultural producers, including personal subsidiary plots, in implementation of an ecological approach in the production of agricultural products. Creation of equal conditions for access to resources for all agricultural producers, these include information resources, modern technologies, product sales market, financial resources, human resources, and etc. 


\section{Discussion}

In her paper, Yu. V. Pavlova [11] notes that for the rational use of natural resources in agribusiness, biotechnology shall gradually gain the dominant position. When ranking the importance of factors for sustainable development of agribusiness, it is necessary to put the factor of environmental sustainability in the first place. P. Ermolenko, O.D. Ermolenko, R.M. Bogdanova [6] also speak of the importance of considering the ecological and economic efficiency of agricultural producers in the agro-industrial complex (AIC).

According to the author, E.A. Lipchenko [17], the development of organic farming at the present stage is faced with a number of difficulties. The main one is that it loses to highintensity production in competition for the food market. This is due to population growth and increasing demand for food, which in turn leads to an intensification of agricultural production and a deterioration in the quality of not only food, but land also. Several authors, T. Skryl, V. Osipov, T. Vorozheikina [16] note that transition to ecological agriculture increases the market regulation of agricultural producers in the reproduction process, which will automatically lead to an improvement in the balance of income distribution among the main participants in the reproduction process, while improving the quality of food for consumers. R.R. Galiev also writes about the need to improve the efficiency of land use by all categories of agricultural producers in his work [19]. The authors Voronkova, O., Sycheva, I., Kovaleva, I., Khasanova, A., Gorovoy, S., Vorozheykina, T. came to the conclusion that one of the main tasks in development of modern agricultural production is precisely the optimization of use of land resources and the choice of such models of rural areas that would ensure their relationship with natural properties [20].

Authors Yu. V. Pavlova, T. M. Vorozheikina [10] identified the main directions of involving households in the industrial and commodity circulation of agricultural products, directions of participation in state programs for the development of the countryside and the agro-industrial complex, the possibility of participating in formation of social security through development of rural areas on the principles of balanced rural settlements. The economic and ecological approach to development of agriculture makes it possible to create a well-grounded structure of an agrarian settlement with the necessary public facilities and infrastructure, which conducts an efficient closed-cycle economic activity with the bioprocessing of organic waste from the residential area and agricultural production, uses renewable energy sources in its activities, providing itself with food, heat -, electricity, gas, biofertilizers and other products. According to the authors, L. A. Zazykina, A. A. Bukova [18], planetary ecosystems can be saved from collapse only by very radical changes in human behavior (including the economy itself).

Therefore, the criteria of the economic and ecological approach to the options for development of rural areas and agriculture offered by the authors are of an evaluative nature, they require additional research and argumentation. Ultimately, all authors are unanimous in the opinion that further development requires a radical change in the attitude of society to nature, to the earth.

\section{Conclusion}

In this situation, the way out is to comprehensively diversify the rural economy, support personal subsidiary plots, facilitate access to material, financial and information resources, support the activities of consulting centers and develop infrastructure that allows the population to receive a decent income. The options for development of rural areas and agriculture considering the economic and environmental approach, are also being implemented in practice. The priority of such development is to improve the quality of life 
of the rural population based on formation of a science-intensive model of agricultural development, the key driving force of which is human capital represented by personal subsidiary plots, environmentally friendly, well-groomed, with a high level of socioeconomic development of rural areas. In the territory of the Kanashsky district of the Chuvash Republic on the basis of Atalanu LLC from 2016 to 2021 experimental work was carried out to create individual elements of a small-scale rural settlement based on the principles of bioecopolis [7]. The results of scientific and experimental design work, the experience of operating a residential building and outbuildings, the established operating mode of innovation gave the basis for development of an innovative project and the opportunity for its subsequent replication. By the Decree of the Administration of the Kanash District of the Chuvash Republic dated February 8, 2021 No. 80 "On Approval of the Comprehensive Program "Social and Economic Development of the Kanash District of the Chuvash Republic for 2020 - 2025", the investment project "Small-scale settlement based on the principles of bio-ecopolis, implemented in the village of Bolshiye Bikshikhi, Kanash District Chuvash Republic - (Project "Bioekopolis")" was included in the strategic plan for development of the municipal district. Bioecopolis in this case is understood as a rural settlement that will provide itself with food, electricity and heat, recycle waste from production and human life thanks to biotechnology. The project is scheduled to be completed in 2023-2025. The expenses for implementation of the innovation project amount to 750 million rubles, where 359,200 thousand rubles - budget financing, and 390,800 thousand rubles - at the expense of investors' own funds, i.e. business.

Therefore, the materials presented in the article are of practical interest for government bodies of different levels, scientific organizations and business. Within implementation of such environmental projects for development of rural areas, the interests of not only the state, business and the scientific community, but also the rural residents and agricultural producers themselves, are converged.

\section{References}

1. V.T. Vodyannikov, Agroengineering, 96, 2 (2020)

2. V.T. Vodyannikov, Bulletin of the Federal State Educational Institution of Higher Professional Education "Moscow State Agroengineering University named after V.P. Goryachkina ", 77, 1 (2017)

3. Declaration of the UN Conference on the Human Environment (Stockholm, 1972)

4. Report on the state and use of agricultural land

5. Russian Federation in 2018 (Federal State Budgetary Scientific Institution "Rosinformagrotech", 2020)

6. Ten Signs that a Green Economy is Gaining Movement (WWF, 2019)

7. V.P. Ermolenko, Scientific Journal of the Russian Research Institute of Melioration Problems, 36, 4 (2019)

8. N.A. Zaitsev, V.V. Lazovsky, S.P. Ivanov, Agro Innovations, 2 (2020)

9. Commoner Barry, The Closing Circle (Gidrometeoizdat, 1974)

10. V.V. Lazovsky (LLC "European Fund for Innovative Development", 2020)

11. Yu. V. Pavlova, Russian Agricultural Economics, 3, 3 (2021)

12. Yu.V. Pavlova, Materials of the International Scientific and Practical Conference (Derzhavinsky Publishing House, 2020)

13. V.D. Popov, M.N. Erokhin, A. Yu. Bryukhanov, E.V. Vasiliev, E.V. Shalavina, Agroengineering, 97, 3 (2020) 
14. Agriculture in Russia, Stat. Rosstat (2019)

15. Federal State Statistics Service (Rosstat), Agriculture, Hunting and Forestry (2019)

16. Ecological footprint of the constituent entities of the Russian Federation (WWF Russia, 2014)

17. T. Skryl, IOP Conference Series: Earth and Environmental Science (2019)

18. E. A. Lipchenko, IOP Conf. Series: Earth and Environmental Science, 650 (2021)

19. L.A. Zazykina, IOP Conference Series: Earth and Environmental Science (2020)

20. R.R. Galiev, Economy of Region, 1, 1 (2015)

21. O. Voronkova, I. Sycheva, I. Kovaleva, A. Khasanova, S. Gorovoy, T. Vorozheykina, Journal of Environmental Management and Tourism, 10, 3 (2019) 